\title{
The Mechanism of Activation of Hormone-Sensitive Lipase in Human Adipose Tissue
}

\author{
John C. Khoo, Alegria A. Aquino, and Daniel Steinberg \\ From the Division of Metabolic Disease, Department of Medicine, University \\ of California, San Diego, La Jolla, California 92037
}

\begin{abstract}
A в S TRACT A partially purified hormone-sensitive triglyceride lipase of human adipose tissue was found to be activated twofold by the addition of cyclic $3^{\prime}, 5^{\prime}$-AMP, $\mathrm{ATP}$, and magnesium ions. Lipase activities against diolein and monoolein were not affected. Addition of protein kinase inhibitor at zero time completely inhibited activation, and this inhibition was prevented by prior addition of an excess of exogenous protein kinase (from rabbit skeletal muscle). Addition of protein kinase inhibitor during the activation step blocked the activation process without a time lag, suggesting that protein kinase operates directly on hormone-sensitive lipase. Further purification yielded a fraction free of protein kinase, and lipase activation in this fraction depended absolutely on addition of exogenous kinase. Incubation of human fat with epinephrine or isoproterenol stimulated lipolysis and caused conversion of nonactivated hormone-sensitive lipase to its activated form, as indicated by a decrease in the activation subsequently obtainable in fractions prepared from such hormone-treated tissues. These findings strongly suggest that the stimulation of lipolysis by hormonal treatment is the consequence of the activation of hormonesensitive triglyceride lipase by cyclic $3^{\prime}, 5^{\prime}$-AMP-dependent protein kinase.
\end{abstract}

\section{INTRODUCTION}

Studies from a number of laboratories indicate that activation of hormone-sensitive lipase in rat adipose tissue is probably linked to cyclic AMP (1-5). Recently, the immediate activating step has been shown to be catalyzed by cyclis AMP-dependent protein kinase $(6,7)$ and to involve the transfer of the terminal phosphate of ATP to the lipase (8). Human adipose tissue differs in several respects from rat adipose tissue. Basal lipolytic

Received for publication 8 May 1973 and in revised form 8 October 1973. activity is lower, as is sensitivity to catecholamines (9, 10). The spectrum of hormone responsiveness is quite different; whereas glucagon, ACTH, and growth hormone are effective stimuli for lipolysis in rat adipose tissue, these hormones have little or no effect on human tissue (11-13). Further, human adipocytes appear to have an $\alpha$-adrenergic receptor mechanism that suppresses lipolysis, while such receptors appear to be lacking in rat adipocytes (14). While there are thus several properties that differentiate hormonal control of human and rat adipose tissue, there are also important parallels. Lipolysis in both is stimulated by theophylline, a phosphodiesterase inhibitor, and by dibutyryl cyclic AMP $(14,15)$. Also, increases in cyclic AMP production have been demonstrated in both species in response to lipolytic hormones $(3,14)$. Thus, the qualitative differences noted above may relate exclusively to the pattern of primary receptor sites; the quantitative differences are not, per se, incompatible with the operation of an activation mechanism in human tissue analogous to that in the metabolically more active rat adipocyte.

The present studies describe the partial purification and characterization of hormone-sensitive lipase from human adipose tissue and the demonstration of its activation by cyclic AMP-dependent protein kinase. The properties of the activation system are described, and evidence is presented to support identification of the protein kinase activation mechanism, demonstrated in cell-free preparations, as the physiologic mode of lipase activation in intact human adipose tissue. Preliminary studies have been reported elsewhere $(16,17)$.

\section{METHODS}

Human subcutaneous adipose tissue was obtained at the time of surgery from three grossly obese subjects undergoing ileo jejunal bypass (L. S., female, age $40 ;$ N. S., female, age 28 ; H. B., male, age 34 ) and from a 54-yrold woman (M. H.) undergoing mastectomy. The patients had nothing by mouth after 6 p.m. the night before surgery. 
The biopsied tissue obtained was minced within $1 \mathrm{~h}$ and incubated at $37^{\circ} \mathrm{C}$ in Krebs-Ringer bicarbonate buffer containing $4 \%$ bovine serum albumin under $95 \% \quad \mathrm{O}_{2}: 5 \% \quad \mathrm{CO}_{2}$ for $1 \mathrm{~h}$. The tissue was then either studied at once or frozen in liquid $\mathrm{N}_{2}$ and stored at $-80^{\circ} \mathrm{C}$ for as long as 1 mo. The tissue was homogenized in a Waring blendor (Waring Products Div., Dynamics Corp. of America, New Hartford, Conn.) with 2 vol of a solution containing 0.25 $M$ sucrose, $1 \mathrm{mM}$ EDTA, and $10 \mathrm{mM}$ Tris buffer, $\mathrm{pH}$ 7.4 , at $4^{\circ} \mathrm{C}$. The homogenate was subjected to low-speed centrifugation to remove cell debris and the bulk of the fat. The extract was then centrifuged at $100,000 \mathrm{~g}$ for 30 min. Lipase activity recovered per gram tissue in the $100,000 \mathrm{~g}$ supernatant fraction was, as expected, much lower than that found in the equivalent fraction from rat adipose tissue-i.e., $50-100$ vs. $2,000-4,000 \mathrm{nmol}$ free fatty acid $(\text { FFA })^{1 / g}$ per $h$. The particle-free supernatant fraction was carefully adjusted to $\mathrm{pH} 5.2$ with $0.1 \mathrm{~N}$ acetic acid. The precipitate formed was centrifuged down at $1,000 \mathrm{~g}$, redissolved in a small volume of buffer containing $20 \%$ glycerol, and stored at $-20^{\circ} \mathrm{C}$. This fraction (designated 5.2 $\mathrm{P}$ fraction) was used in all the studies to be described unless otherwise specified. Its specific activity was 6-19 times that of the $100,000 \mathrm{~g}$ supernatant fraction, and recoveries ranged from 60 to $100 \%$. The specific activity of this fraction ranged from 98 to 250 nmol FFA released/ $\mathrm{mg}$ of protein per $\mathrm{h}$. In one experiment, the enzyme was further purified by taking up the $5.2 \mathrm{P}$ fraction in a solution containing $0.25 \mathrm{M}$ sucrose, $1 \mathrm{mM}$ EDTA, and 10

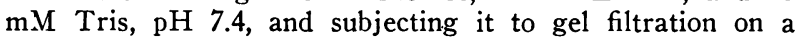
$4 \%$ agarose column. Over $53 \%$ of the activity emerged in the void peak. The effluent was adjusted to density 1.15 by addition of sucrose and was centrifuged in a BeckmanSpinco 40.3 rotor (Beckman Instruments Inc., Spinco Div., Palo Alto, Calif.) at $40,000 \mathrm{rpm}$ for $48 \mathrm{~h}$. Over $90 \%$ of the activity was recovered in the top $1.5 \mathrm{ml}$ of the centrifuge tube. The specific activity of this floated fraction was 29 times that of the original $100,000 \mathrm{~g}$ supernatant fraction.

Some lipoprotein lipase activity was recovered in the 5.2 $\mathrm{P}$ fraction. Its contribution to observed triglyceride lipase activity was minimal at $\mathrm{pH} 7.0$ in the absence of activator. However, by adding serum or a specific lipoprotein apoprotein activator (apoLp-Glu) and by assaying at $\mathrm{pH} 8.2$, significant lipoprotein lipase activity was measurable.

Unless otherwise stated, the activation of lipase fractions was carried out in a volume of $0.2 \mathrm{ml}$ at $30^{\circ} \mathrm{C}$ for 10 min at $\mathrm{pH} 8.0$, which was shown to be the $\mathrm{pH}$ optimum for the activation step. The system consisted of $50 \mathrm{mM}$ Tris, $\mathrm{pH} 8.0,1 \mathrm{mM}$ dithiothreitol, $0.5 \mathrm{mM}$ ethyleneglycolbis ( $\beta$-aminoethyl ether) $N, N^{\prime}$-tetraacetic acid (EGTA), 5 $\mathrm{mM}$ magnesium acetate, and $1.0 \mathrm{mM}$ theophylline, either in the absence (incomplete system) or in the presence (complete system) of $0.5 \mathrm{mM} \mathrm{ATP}$ and $0.01 \mathrm{mM}$ cyclic AMP.

The $\mathrm{pH}$-activity curves for both the nonactivated and activated preparations were indistinguishable, showing a rather broad peak between $\mathrm{pH} 6.8$ and 7.4. Therefore, assays of lipase activity were routinely carried out at $\mathrm{pH}$ 7.0. Assay of hormone-sensitive lipase was initiated by

${ }^{1}$ Abbreviations used in this paper: apoLp-Glu, the apoprotein with C-terminal glutamic acid isolated from human very low density lipoprotein; EGTA, ethyleneglycol bis( $\beta$-aminoethyl ether) $N, N^{\prime}$-tetraacetic acid; FFA, free fatty acid.
TABLE I

Magnesium Ion Requirement for Lipase Actiration by Endogenous Protein Kinase

\begin{tabular}{cccc}
\hline $\begin{array}{c}\mathbf{M g}^{2+} \\
\text { concen- } \\
\text { tration }\end{array}$ & $\begin{array}{c}\text { Incomplete } \\
\text { system* } \\
\left.\text { (minus } \mathrm{Mg}^{2+}\right)\end{array}$ & $\begin{array}{c}\text { Complete } \\
\text { system* } \\
\text { (minus } \mathbf{M g}^{2+} \text { ) }\end{array}$ & $\begin{array}{c}\text { Percentage } \\
\text { activation }\end{array}$ \\
\cline { 1 - 3 }$m .1 \Gamma$ & \multicolumn{2}{c}{ nmol FFA/mg protein per $h$} & \\
0 & $224,219(222) \ddagger$ & $227,231(229)$ & 0 \\
0.1 & $235,239(237)$ & $233,234(234)$ & 0 \\
0.5 & $229,237(233)$ & $257,266(262)$ & 13 \\
1.0 & $243,237(240)$ & $480,481(481)$ & 100 \\
5.0 & $249,251(250)$ & $502,511(506)$ & 102 \\
10.0 & $243,248(246)$ & $505,510(508)$ & 107 \\
20.0 & $250,246(248)$ & $507,522(515)$ & 107 \\
\end{tabular}

* Composition of activation mixtures as described under Methods, except that $\mathrm{Mg}^{2+}$ was omitted and replaced by the concentrations of $\mathrm{Mg}^{2+}$ shown in the first column.

$\ddagger$ Results of duplicate enzyme assays; mean values in parentheses.

adding to the activation mixture $2 \mathrm{ml}$ of a substrate mixture containing $0.42 \mathrm{mM}\left[{ }^{14} \mathrm{C}\right]$ triolein $(238,000 \mathrm{cpm} / \mu \mathrm{mol})$, $30 \mathrm{mM}$ EDTA, $40 \mathrm{mM}$ Na-phosphate buffer, $\mathrm{pH} 7.0$, and $2 \%$ bovine serum albumin (Fraction V, Armour Pharmaceutical Co., Chicago, Ill.) and incubations were carried out at $30^{\circ} \mathrm{C}$ for $1 \mathrm{~h}$. The reactions with complete and incomplete systems were linear for $90 \mathrm{~min}$, at which time no more than $18 \%$ of the triolein had been hydrolyzed. The rate of triolein hydrolysis increased linearly with increasing amounts of the $5.2 \mathrm{P}$ fraction over the range of enzyme activities studied. The reactions were stopped by adding $5 \mathrm{ml}$ of Dole's extraction mixture (18). Fatty acids were isolated from the heptane phase by the resin method of Kelley (19), as modified by Huttunen, Ellingboe, Pittman, and Steinberg (20). The excellent reproducibility of the lipase assay is indicated by the representative results shown in Table I. Duplicate assays (14 pairs) agreed within $1.8 \pm 0.2 \%$ (mean percentage difference $\pm \mathrm{SEM}$ ). The assays of nonactivated enzyme (incomplete system) yielded a mean value of $240 \pm 4 \mathrm{nmol} \mathrm{FFA} / \mathrm{mg}$ protein per $\mathrm{h}$. This is a maximum estimate of the error, since there may have been a small effect of $\mathrm{Mg}^{2+}$ at concentrations above $1 \mathrm{mM}$.

Labeled triolein, diolein (a mixture of 1,3 and 2,3 isomers), and monoolein (presumably an equilibrium mixture of 1 and 2 isomers) were obtained from DHOM Products, Ltd., North Hollywood, Calif. $\left[1-{ }^{14} \mathrm{C}\right]$ oleic acid was distributed randomly among the acylated position in all the labeled substrates. Nonradioactive triolein, diolein, and monoolein were obtained from Sigma Chemical Co., St. Louis, Mo. Triolein emulsions were prepared by sonification of a mixture of $\left[{ }^{14} \mathrm{C}\right]$ triolein and unlabeled triolein in $5 \%$ gum arabic, as previously described (20). Diolein emulsions were prepared in the same way. Since monoolein did not yield a homogeneous emulsion with $5 \%$ gum arabic, the emulsion was prepared by mixing it with $10 \mathrm{mM}$ taurodeoxycholate, $\mathrm{pH} 7.0$, on a Vortex mixer (Scientific Industries, Inc., Queens Village, N. Y.) as previously described (21).

Glycerol was determined enzymatically by the method of Wieland (22). The NADH formed was read in a Farrand spectrofluorometer (Mark I, Farrand Optical Co., 


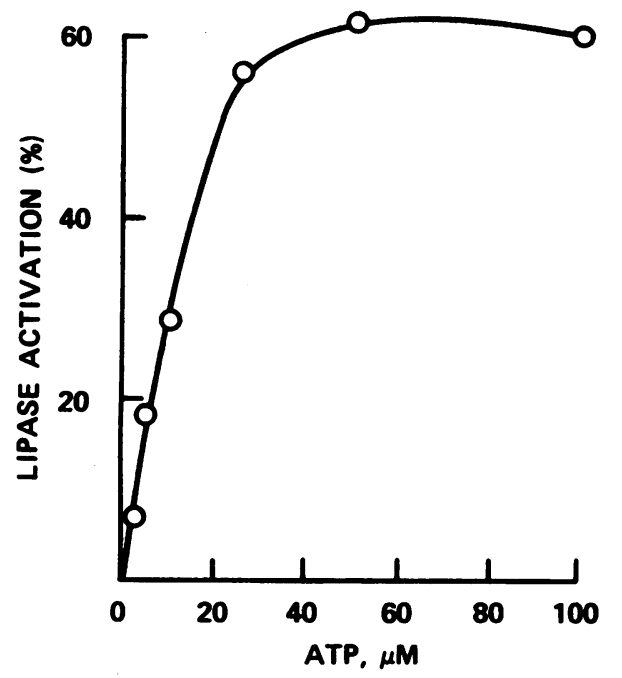

Figure 1 ATP dependence of hormone-sensitive lipase activation. Lipase was activated with the incomplete system (see Methods) plus cyclic AMP $(10 \mu \mathrm{M})$ and increasing concentrations of ATP (from 0 to $100 \mu \mathrm{M}$ ) at $30^{\circ} \mathrm{C}$ for $5 \mathrm{~min}$. No exogenous protein kinase was added. The activation was terminated by adding $2 \mathrm{ml}$ of substrate mixture, and lipase activity was assayed for $1 \mathrm{~h}$ at $30^{\circ} \mathrm{C}$.

Inc., Valhalla, N. Y.). Glycerokinase and $\alpha$-glycerolphosphate dehydrogenase were purchased from Sigma Chemical Co. Protein was determined as described by Lowry, Rosebrough, Farr, and Randall (23).

Protein kinase was purified from rabbit skeletal muscle

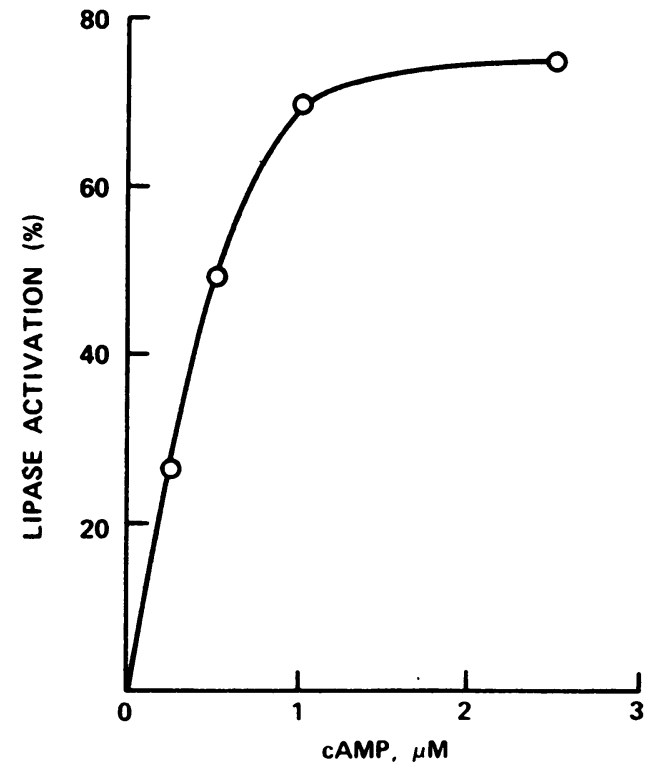

Figure 2 Cyclic AMP (cAM.P) dependence of hormonesensitive lipase activation. Activation was carried out in the presence of $0.5 \mathrm{mM}$ ATP and increasing concentrations of cyclic AMP. Other conditions were as described in the legend to Fig. 1. by the procedure of Walsh, Perkins, and Krebs (24) through the first DEAE-cellulose chromatography step. It was devoid of lipase activity. Protein kinase inhibitor was also purified from rabhit skeletal muscle according to the method of Walsh et al. (25). The lipoprotein apoprotein with C-terminal glutamic acid (apoLp-Glu), generously provided by Dr. W. Virgil Brown, was purified from the very low density lipoprotein fraction of a patient with type V hyperlipoproteinemia (26).

\section{RESULTS}

Characteristics of the activation system. Activation of partially purified hormone-sensitive lipase (5.2 P fraction) required addition of three primary cofactors: $\mathrm{Mg}^{2+}$, ATP, and cyclic AMP. Omission of any one of these three primary cofactors markedly reduced or abolished activation, as shown below.

The requirement for $\mathrm{Mg}^{2+}$ is demonstrated by the results in Table I. Under the activation conditions used, with $0.5 \mathrm{mM}$ EGTA present, $1-5 \mathrm{mM}$ added $\mathrm{Mg}^{2+}$ yielded maximum activation. Higher concentrations of $\mathrm{Mg}^{2+}$, up to $20 \mathrm{mM}$, did not inhibit the activation process, nor did

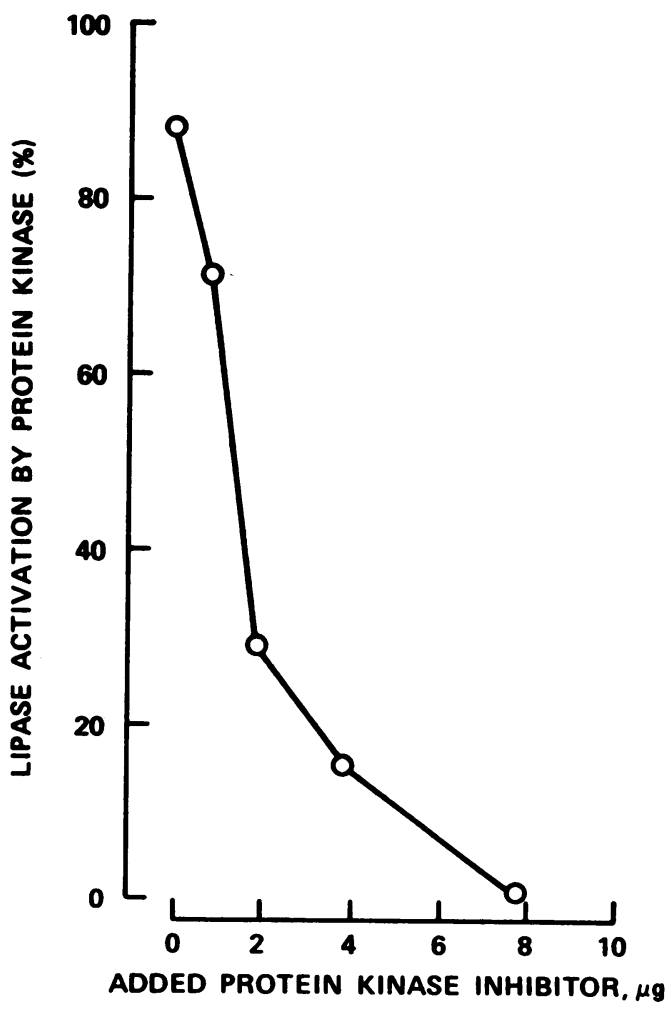

FIgURE 3 The effect of protein kinase inhibitor on the activation of hormone-sensitive lipase. Lipase in the $\mathrm{pH}$ 5.2 precipitate fraction was activated as described under Methods. The indicated amounts of protein kinase inhibitor were added just before the addition of the $5.2 \mathrm{P}$ fraction (final volume $0.2 \mathrm{ml}$ ). Lipase assay was initiated by the addition of $2 \mathrm{ml}$ of substrate containing $0.42 \mathrm{mM}\left[{ }^{14} \mathrm{C}\right]-$ triolein. 
they inhibit either the nonactivated or the activated form of the lipase.

Activation as a function of increasing concentrations of ATP from $1 \mu \mathrm{M}$ to $100 \mu \mathrm{M}$ at a constant concentration of cyclic AMP $(10 \mu \mathrm{M})$ is shown in Fig. 1. Halfmaximal activation was obtained at about $8 \mu \mathrm{M}$. Activation as a function of increasing concentrations of cyclic AMP from $0.25-2.5 \mu \mathrm{M}$ in the presence of a constant concentration of ATP $(0.5 \mathrm{mM})$, is shown in Fig. 2. Half-maximal activation was obtained at about $3 \times 10^{-7} \mathrm{M}$. Activation specifically required ATP and cyclic AMP. Substitution of ITP, GTP, thymidine triphosphate (dTTP), or UTP for ATP or substitution of cyclic GMP, cyclic IMP, or cyclic UMP for cyclic AMP yielded little or no activation (data not shown).

Protein kinase dependency of the activation. To prove that the activation by cyclic AMP and ATP- $\mathrm{Mg}^{2+}$ was due to endogenous protein kinase in the $5.2 \mathrm{P}$ fraction, a specific inhibitor of protein kinase was used (25). Addition of $7.8 \mu \mathrm{g}$ of the protein kinase inhibitor to the complete system completely blocked activation (Fig. 3). The inhibitory effect was a function of the amount of protein kinase inhibitor added, $50 \%$ inhibition being obtained with addition of about $2 \mu \mathrm{g}$ (final concentration $10 \mu \mathrm{g} / \mathrm{ml}$ ) (Fig. 3). This inhibition could be overcome by adding back purified protein kinase from rabbit skeletal muscle as shown in Fig. 4, thus ruling out nonspecific effects of the protein kinase inhibitor fraction. The maximal activation of hormone-sensitive lipase due to the addition of even large amounts of exogenous protein kinase did not exceed that obtained in the absence of protein kinase inhibitor, indicating that there was sufficient endogenous protein kinase in the $5.2 \mathrm{P}$ fraction to completely activate during the 10 -min preincubation pe-

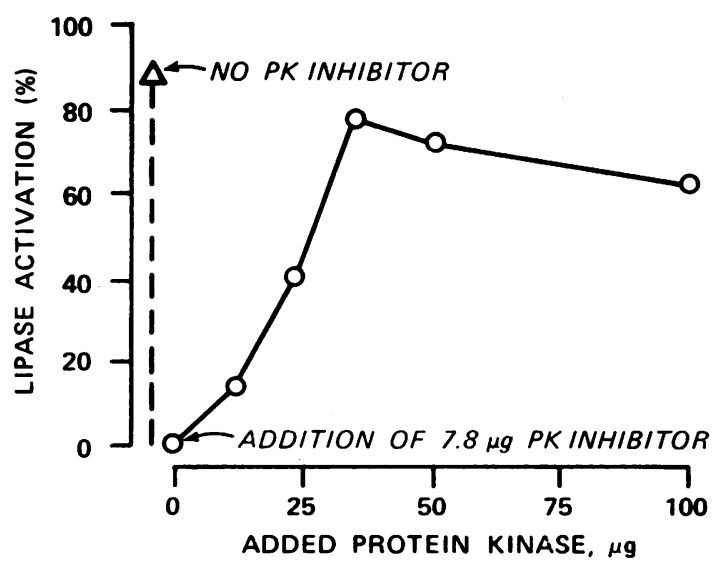

FIgURE 4 Reversal of the effects of protein kinase (PK) inhibitor by addition of exogenous purified protein kinase. Various amounts of purified protein kinase were added at zero time to a series of tubes containing lipase together with $7.8 \mu \mathrm{g}$ of protein kinase inhibitor.

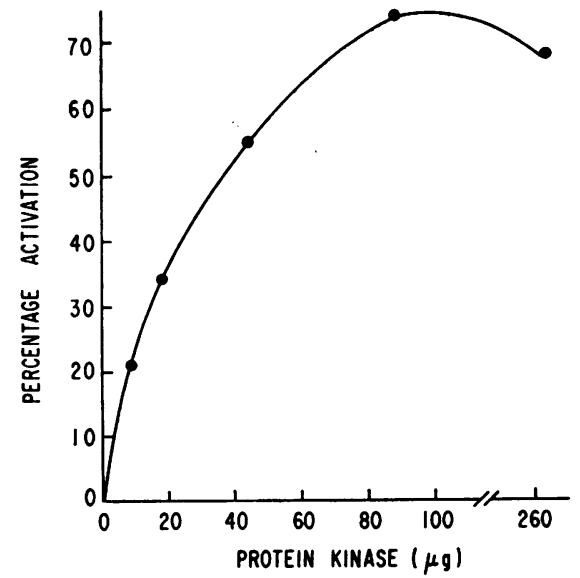

FIgURE 5 Requirement for added protein kinase for hormone-sensitive lipase activation in a more highly purified fraction (1.15 floating fraction; see Methods). Lipase was activated in a total volume of $0.4 \mathrm{ml}(0.2 \mathrm{ml}$ of $\mathrm{d} 1.15$ floating fraction plus $0.2 \mathrm{ml}$ of complete activation system).

riod. When the enzyme in the $5.2 \mathrm{P}$ fraction was further purified by gel filtration and by flotation at density 1.15 , as described under Methods, activation depended absolutely on the addition of exogenous protein kinase, as shown in Fig. 5.

The activation of human hormone-sensitive lipase by protein kinase could be an indirect process analogous to the system for activation of phosphorylase. In that case, cyclic AMP-dependent protein kinase activates phosphorylase kinase, which then in turn, activates phosphorylase in a reaction not dependent on cyclic AMP (24). To test for the possible participation of a lipase kinase analogous to phosphorylase kinase, protein kinase inhibitor was added during the course of the activation step. If there were an intermediate enzyme ("lipase kinase"), activation might be expected to continue for some time, even after the protein kinase activity had been completely inhibited. As shown in Fig. 6, when protein kinase inhibitor was added at $10 \mathrm{~min}$, the activation process was immediately and completely blocked. Addition of an excess amount of protein kinase $(80 \mu \mathrm{g})$ overcome this inhibition and allowed activation to continue (Fig. 6).

Conversion of lipase to the activated form by hormone treatment of intact tissue. If the activation of hormone-sensitive lipase by cyclic AMP-dependent protein kinase reflects the physiologic process of activation, it would be anticipated that homogenates prepared from tissues previously incubated with lipolytic hormones would contain lipase predominantly in the activated form and therefore show a smaller percentage increase in activity in response to the cyclic AMP system. Pieces of human fat were incubated for $1 \mathrm{~h}$ with epinephrine or isoproterenol. At the end of the incubation, the tissues 
TABLE II

Effects of Previous Incubation of Intact Tissue with Hormones on Cyclic AMP-Dependent Activation of Lipase in Cell-Free Extracts

\begin{tabular}{|c|c|c|c|c|}
\hline \multirow[b]{2}{*}{ Hormone added } & \multirow{2}{*}{$\begin{array}{l}\text { Rate of } \\
\text { glycerol } \\
\text { release from } \\
\text { intact tissue }\end{array}$} & \multicolumn{3}{|c|}{$\begin{array}{l}\text { Activation in the } 5.2 \mathrm{P} \text { fractions prepared from } \\
\text { tissue at end of incubation }\end{array}$} \\
\hline & & $\begin{array}{l}\text { Incomplete } \\
\text { system }\end{array}$ & $\begin{array}{l}\text { Complete } \\
\text { system }\end{array}$ & $\begin{array}{l}\text { Percentage } \\
\text { activation }\end{array}$ \\
\hline & $\begin{array}{l}n m o l / g \\
\text { lissue per } h\end{array}$ & \multicolumn{2}{|c|}{ nmol FFA / mg protein per $h$} & \\
\hline Exp 1 (subject N. S.) & & & & \\
\hline None & 228 & 221 & 439 & 99 \\
\hline Epinephrine $(1 \mu \mathrm{M})$ & 458 & 268 & 419 & 56 \\
\hline Isoproterenol $(1 \mu \mathrm{M})$ & 688 & 349 & 394 & 13 \\
\hline \multicolumn{5}{|l|}{ Exp 2 (subject M. H.) } \\
\hline None & - & 109 & 166 & 52 \\
\hline Epinephrine $(10 \mu \mathrm{M})$ & - & 164 & 183 & 12 \\
\hline
\end{tabular}

were homogenized and $5.2 \mathrm{P}$ fractions were prepared from each. Then the percentage activation obtainable with cyclic AMP-ATP was determined.

As shown in Table II, the percentage activation obtained in tissues incubated in the presence of hormone was sharply reduced. In exp 1 it fell from $99 \%$ to $13 \%$

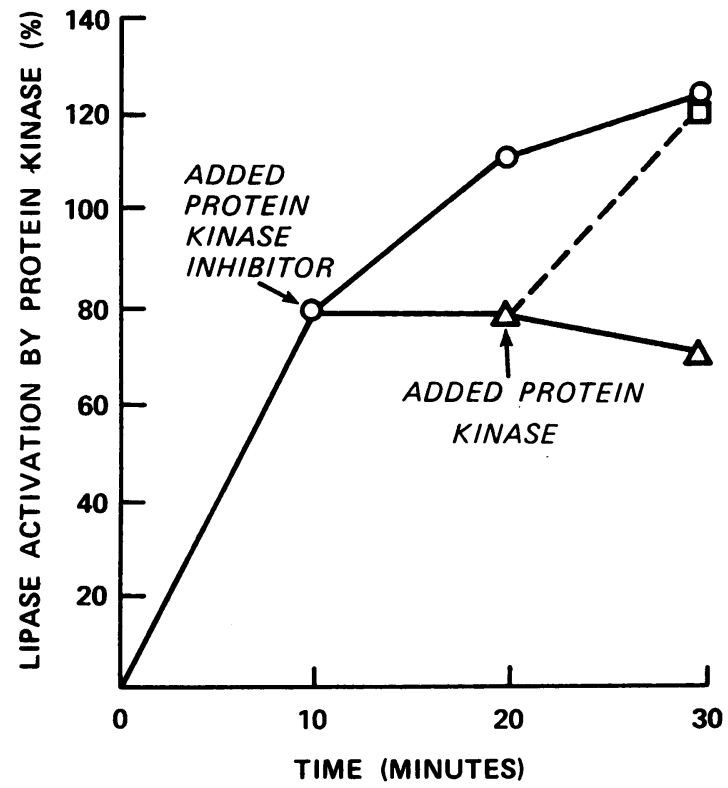

FIGURE 6 Arrest of the activation process on addition of protein kinase inhibitor and restoration of activation on addition of excess protein kinase. Activation of lipase was initiated using the standard complete system, and lipase activity was determined at $10 \mathrm{~min}$ intervals (O). At 10 min, an aliquot was added to a tube containing protein kinase inhibitor $(7.8 \mu \mathrm{g})$. At $20 \mathrm{~min}$ and $30 \mathrm{~min}$, aliquots of this mixture were assayed $(\triangle)$. At $20 \mathrm{~min}$, an excess of protein kinase was added $(80 \mu \mathrm{g})$ and lipase activity was determined at $30 \mathrm{~min}(\square)$. after incubation with $1 \mu \mathrm{M}$ isoproterenol, a potent $\beta$-adrenergic agent (12). Epinephrine at $1 \mu \mathrm{M}$ was less effective. At $10 \mu \mathrm{M}(\exp 2)$, epinephrine reduced activation from 52 to $12 \%$. The minimal activation seen in fractions from hormone-treated tissue (13 and 12\%) suggests that almost all of the lipase was converted to the activated form during incubation with the hormones.

Effects of the activation system on hydrolysis of diolein and monoolein. As shown in Table III, the $5.2 \mathrm{P}$ fraction contained much higher levels of activity (about 10 -fold higher) against diolein and monoolein than against triolein. However, only the lipase activity against triolein was enhanced by the activation system (110\%), whereas the lipase activities against diolein and monoolein were virtually unaltered.

Effects on lipoprotein lipase. It has been proposed that cyclic AMP might be involved in regulation of lipoprotein lipase, the effect being in a direction opposite to that of its effects on hormone-sensitive lipase (27). In the present studies, the lipoprotein lipase content of the tissue was reduced by incubation of the tissue before homogenization, as previously described (20), but there

TABLE III

Effects of Activation System on Enzymatic Activities against Tri-, Di-, and Monoolein

\begin{tabular}{|c|c|c|c|}
\hline \multirow[b]{2}{*}{ Substrate } & \multicolumn{2}{|c|}{ Lipolytic activity } & \multirow[b]{2}{*}{$\begin{array}{l}\text { Percentage } \\
\text { change }\end{array}$} \\
\hline & $\begin{array}{l}\text { Incomplete } \\
\text { system }\end{array}$ & $\begin{array}{l}\text { Complete } \\
\text { system }\end{array}$ & \\
\hline & \multicolumn{2}{|c|}{$n m o l F F A / m g$ protein per $h$} & \\
\hline Triolein $(0.43 \mathrm{mM})$ & 98 & 208 & +110 \\
\hline Diolein $(0.5 \mathrm{mM})$ & 1,240 & 1,150 & -7 \\
\hline Monoolein $(0.5 \mathrm{mM})$ & 870 & 920 & +6 \\
\hline
\end{tabular}


TABLE IV

Effects of Serum and ApoLp-Glu Peptide* on the Activatability of Lipase by Endogenous Protein Kinase

\begin{tabular}{lccccc}
\hline & \multicolumn{2}{c}{ Lipolytic activity } & & \\
\cline { 2 - 3 } \multicolumn{1}{c}{ Additions } & $\begin{array}{c}\text { Incomplete } \\
\text { system }\end{array}$ & $\begin{array}{c}\text { Complete } \\
\text { system }\end{array}$ & $\begin{array}{c}\text { Absolute } \\
\text { change }\end{array}$ & $\begin{array}{c}\text { Percentage } \\
\text { change }\end{array}$ \\
\hline & nmol FFA/mg & protein per $h$ & & \\
None & 120 & 200 & 80 & +67 \\
Serum $(50 \mu \mathrm{l})$ & 486 & 532 & 56 & +9.5 \\
ApoLp-Glu peptide $(10 \mu \mathrm{g})$ & 470 & 520 & 50 & +10.6 \\
\hline
\end{tabular}

* ApoLp-Glu peptide (glutamic acid C-terminal apoprotein isolated from very low density lipoproteins) is a potent activator of lipoprotein lipase (27).

was still some residual lipoprotein lipase activity in the $5.2 \mathrm{P}$ fraction. Even though lipase assays were carried out at $\mathrm{pH} 7.0$, one might therefore anticipate some contribution from lipoprotein lipase if activator were added. As shown in Table IV, addition of serum or of the lipoprotein apoprotein activator, apoLp-Glu (26), markedly enhanced triglyceride lipase activity. An attempt was made, then, to determine whether the cyclic AMP-dependent protein kinase system affected this lipoprotein lipase activity.

As shown in Table IV, the addition of cyclic AMP and ATP- $\mathrm{Mg}^{2+}$ in the absence of a lipoprotein lipase activator enhanced lipolytic activity by $67 \%$. Addition of either serum or apoLp-Glu increased basal lipase activity almost fourfold, the large increment presumably being due to lipoprotein lipase in the preparation. However, the incubation with cyclic AMP and ATP-Mg' had little or no effect on this activity (i.e., there was no apparent deactivation). If anything, there was a slight increase in activity, the absolute magnitude of which was, within experimental error, the same as that seen in the absence of serum or apoLp-Glu. The results suggested that the hormone-sensitive lipase in the preparation was activated in the usual way but that lipoprotein lipase activity was unaffected by the cyclic AMP-dependent protein kinase system.

\section{DISCUSSION}

The results presented are compatible with the scheme for hormone-regulated activation of lipase shown in Fig. 7. Previous studies established that hormone-receptor interaction leads to increased adenylate cyclase activity and the generation of higher levels of cyclic AMP, Sutherland and Rall's ubiquitous "second messenger" (28). Our studies link second messenger generation to lipase activation through the action of a cyclic AMP-dependent protein kinase. Mediation of cyclic AMP action by way of protein kinase was first demonstrated by Walsh, Perkins, and Krebs in the activation of phosphorylase kinase (24) which then in turn activates phosphorylase, and by Larner and VillarPalasi in the conversion of glycogen synthase from the I to the $\mathrm{D}$ form (29). The properties of protein kinase in human adipose tissue have not been elucidated, but in a variety of other tissues its activation has been shown to be effected by binding of cyclic AMP which causes dissociation of a receptor unit-catalytic unit complex (inactive in the absence of cyclic AMP), liberating the free catalytic unit (cyclic AMP-independent) (30).

The specificity of the endogenous protein kinase with regard to cyclic nucleotide and nucleoside triphosphate cofactor requirements was similar to that of rabbit muscle and rat adipose tissue protein kinase. Corbin, Brostrom, Alexander, and Krebs have pointed out the general similarities of cyclic AMP-dependent protein kinases from different sources (31). Quantitative comparisons are not too informative considering the limited purity of the systems studied, but it can be noted that half-maximum rates of activation were obtained at about

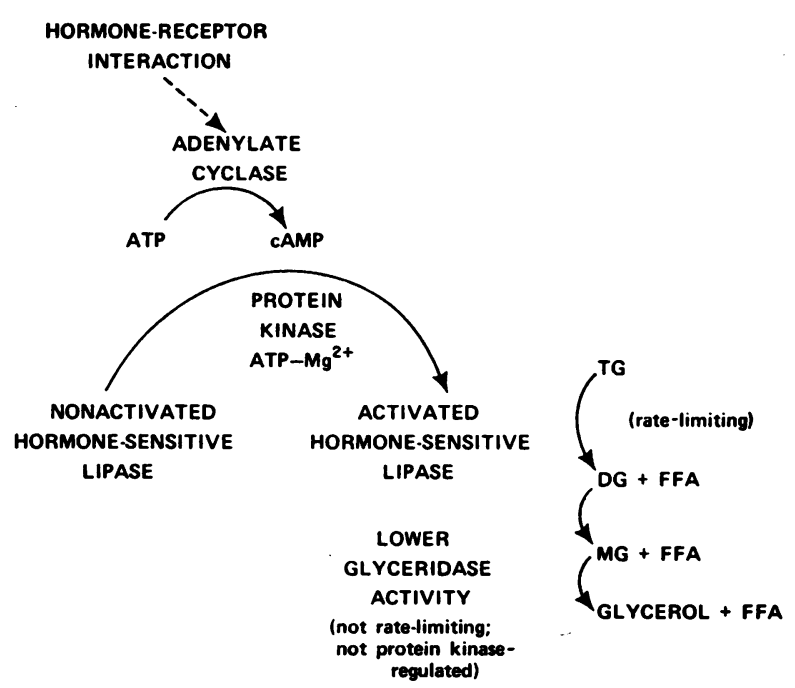

Figure 7 Scheme for activation of hormone-sensitive lipase in human adipose tissue. TG, triglyceride; DG, diglyceride; MG, monoglyceride; and cAMP, cyclic AMP. 
$8 \mu \mathrm{M} \mathrm{ATP}$ and $3 \times 10^{-7} \mathrm{M}$ cyclic AMP, values similar to, but somewhat higher than, those reported for the activation of the rat enzyme by exogenous (rabbit muscle) protein kinase (8).

In Fig. 7, the protein kinase is shown acting directly on the lipase. The possibility that protein kinase instead activates an intermediate enzyme (analogous to phosphorylase kinase) which then in turn activates the lipase could not be ruled out a priori in this only partially purified system. However, the fact that addition of protein kinase inhibitor during the activation process abruptly and completely arrested further activation rules against such a possibility (Fig. 6).

Is the increase in lipolytic activity induced by hormones in intact adipose tissue effected by the activation system demonstrated in our cell-free extracts? If so, the lipase in homogenates prepared from tissue previously exposed to lipolytic hormones should already be largely in the activated form and consequently undergo little or no further activation by the cyclic AMP-dependent system. This was shown to be the case (Table II), strengthening the conclusion that activation in the intact cell is indeed linked to cyclic AMP-dependent protein kinase. The characteristic action of cyclic AMP. dependent protein kinase, of course, is to phosphorylate acceptor proteins. This has been explicitly demonstrated in the case of three enzymes: phosphorylase kinase (24), glycogen synthase (30), and rat hormone-sensitive lipase (8). A similar mechanism would be anticipated in the case of the human hormone-sensitive lipase, but direct examination of this must await more extensive purification of the enzyme.

The $5.2 \mathrm{P}$ fraction contained high levels of activity against diolein and monoolein, but neither of these was affected by cyclic AMP-ATP under conditions that doubled activity against triolein. We conclude, as shown in Fig. 7, that the splitting of the first ester bond in triglycerides is rate limiting. The high basal activity of the lower glyceridases is evidently ample to maintain FFA and glycerol production at a rate determined by the fully-activated hormone-sensitive triglyceride lipase.

On the basis that reciprocal changes in lipoprotein lipase activity and hormone-sensitive lipase activity are observed in adipose tissue under certain conditions (hormonal stimulation of FFA mobilization, starvation, refeeding), it has been postulated that lipoprotein lipase activity might also be regulated via cyclic AMP, (i.e., it might be inactivated in the presence of elevated cyclic AMP levels) (27). However, we found that the activity of lipoprotein lipase in the $5.2 \mathrm{P}$ fraction was not altered perceptibly by addition of cyclic AMP and ATP- $\mathrm{Mg}^{2+}$. Attempts to demonstrate an effect of cyclic AMP-dependent protein kinase on lipoprotein lipase extracted from acetone powders of human adipose tissue and released from rat fat pads into a heparin-con- taining medium have been negative. We have also examined the effects of cyclic AMP-dependent protein kinase on lipoprotein lipase from acetone powders of human milk and from human post-heparin plasma, and these preliminary results have again been negative (unpublished results). These results lend no support to the proposition that cyclic AMP-dependent protein kinase is involved in regulation of lipoprotein lipase activity. That cyclic AMP may have some other role (e.g., in regulation of enzyme biosynthesis) remains a real possibility. Alternative explanations for the reciprocal variation in activities of these two lipases have been proposed. Thus, Patten (32) has noted correlations between falling ATP levels and falling levels of lipoprotein lipase. Nikkilä and Pykälisto (33) have noted an inverse correlation between FFA levels in adipose tissue and lipoprotein lipase activity.

Hormone stimulation of lipolysis in human adipose tissue appears to be effected by a mechanism basically similar to that in rat adipose tissue (8). Sidhu and Emery have reported activation of lipolytic activity in crude homogenates of bovine adipose tissue by addition of cyclic AMP and ATP- $\mathrm{Mg}^{2+}$ (34). We have recently demonstrated marked activation of lipase in cell-free fractions of chicken adipose tissue (unpublished results). Thus, it may be that many of the reported species differences in hormonal response patterns relate primarily, if not exclusively, to differences in the specificity of plasma membrane receptors and their linked adenylate cyclase systems. The mechanism for conversion of lipase to its activated form, on the other hand, may be basically the same in all species. The interesting difference between human fat and rat fat with regard to $\alpha$-adrenergic receptors observed by Burns and Langley (14) may again relate to regulation of cyclic AMP levels via the receptor-adenylate cyclase complex and does not necessarily require postulation of an independent mechanism for regulation of lipase activity. Burns and Langley showed that in human fat (but not in rat fat) epinephrine, in the presence of a $\beta$-adrenergic blocker (propranolol), reduces the rate of glycerol release well below basal values. The implication is that $\alpha$-receptors mediate a decrease in lipase activity. In the context of the present results, this would imply that even in the basal state a significant fraction of the hormone-sensitive lipase is maintained in its activated form and that stimulation of $\alpha$-receptors decreases cyclic AMP levels. However, the possibility that suppression of lipolytic activity in human fat by $\alpha$-adrenergic agonists represents an alternative mechanism for control or expression of lipase activity cannot be ruled out.

\section{ACKNOWLEDGMENTS}

Protein kinase and protein kinase inhibitor from rabbit skeletal muscle were the generous gifts of $\mathrm{Dr}$. Steven E. 
Mayer. We wish to thank Dr. Marshall J. Orloff, Dr. Eugene F. Bernstein, and their surgical colleagues Dr. Gerald W. Peskin and Dr. Warren O. Kessler for the tissue specimens used in these studies. We also are indebted to Dr. W. Virgil Brown for the activator apoproteins he provided.

This work was supported by U. S. Public Health Service grants HL-14197 and HL-12373 and by a grant from The Weight Watchers Foundation, Inc.

\section{REFER ENCES}

1. Rizack, M. A. 1964. Activation of an epinephrinesensitive lipolytic activity from adipose tissue by adenosine-3',5'-phosphate. J. Biol. Chem. 239: 392.

2. Butcher, R. W., R. J. Ho, H. C. Meng, and E. W. Sutherland. 1965. Adenosine $3^{\prime}, 5^{\prime}$-monophosphate in biological material. II. The measurement of adenosine$3^{\prime}, 5^{\prime}$-monophosphate in tissues and the role of the cyclic nucleotide in the lipolytic response of fat to epinephrine. J. Biol. Chem. 240: 4515.

3. Weiss, B., J. I. Davies, and B. B. Brodie. 1966. Evidence for a role of adenosine $3^{\prime}, 5^{\prime}$-monophosphate in adipose tissue lipolysis. Biochem. Pharmacol. 15: 1553.

4. Vaughan, M., and D. Steinberg. 1963. Effect of hormones on lipolysis and esterification of free fatty acids during incubation of adipose tissue in vitro. J. Lipid Res. 4 : 193.

5. Manganiello, V. C., F. Murad, and M. Vaughan. 1971. Effects of lipolytic and antilipolytic agents on cyclic $3^{\prime}, 5^{\prime}$-adenosine monophosphate in fat cells. J. Biol. Chem. 246: 2195 .

6. Huttunen, J. K., D. Steinberg, and S. E. Mayer. 1970. ATP-dependent and cyclic AMP-dependent activation of rat adipose tissue lipase by protein kinase from rabbit skeletal muscle. Proc. Natl. Acad. Sci. U. S. A. 67: 290.

7. Corbin, J. D., E. M. Reimann, D. A. Walsh, and E. G. Krebs. 1970. Activation of adipose tissue lipase by skeletal muscle cyclic adenosine $3^{\prime}, 5^{\prime}$-monophosphatestimulated protein kinase. J. Biol. Chem. 245: 4849.

8. Huttunen, J. K., and D. Steinberg. 1971. Activation and phosphorylation of purified adipose tissue hormone-sensitive lipase by cyclic AMP-dependent protein kinase. Biochim. Biophys. Acta. 239: 411.

9. Gries, F. A., and J. Steinke. 1967. Insulin and human adipose tissue in vitro: a brief review. Metab. (Clin. Exp.). 16: 693.

10. Björntorp, P. 1964. The fatty acid release and lipolysis of human subcutaneous adipose tissue in vitro. Metab. (Clin. Exp.). 13: 1318.

11. Mosinger, B., E. Kuhn, and V. Kujalová. 1965. Action of adipokinetic hormones on human adipose tissue in vitro. J. Lab. Clin. Med. 66: 380.

12. Burns, T. W., P. E. Langley, and G. A. Robison. 1971. Adrenergic receptors and cyclic AMP in the regulation of human adipose tissue lipolysis. Ann. N. Y. Acad. Sci. 185 : 115.

13. Galton, D. J., and G. A. Bray. 1967. Studies on lipolysis in human adipose cells. J. Clin. Invest. 46: 621.

14. Burns, T. W., and P. E. Langley. 1970. Lipolysis by human adipose tissue: the role of cyclic $3^{\prime}, 5^{\prime}$-adenosine monophosphate and adrenergic receptor sites. J. Lab. Clin. Med. 75: 983.

15. Moskowitz, J., and J. N. Fain. 1969. Hormonal regu- lation of lipolysis and phosphorylase activity in human fat cells. J. Clin. Invest. 48: 1802.

16. Khoo, J. C., W. W. Fong, and D. Steinberg. 1972. Activation of hormone-sensitive lipase from adipose tissue by cyclic AMP-dependent protein kinase. Biochem. Biophys. Res. Commun. 49 : 407.

17. Khoo, J. C., and D. Steinberg. 1973. The mechanism of activation of hormone-sensitive lipase in human adipose tissue. Clin. Res. 21: 629.

18. Dole, V. P. 1956. A relation between non-esterified fatty acids in plasma and the metabolism of glucose. J. Clin. Invest. $35: 150$.

19. Kelley, T. F. 1968. Rapid assay of labeled free fatty acids in mixtures of labeled lipids. J. Lipid Res. 9: 799.

20. Huttunen, J. K., J. Ellingboe, R. C. Pittman, and D. Steinberg. 1970. Partial purification and characterization of hormone-sensitive lipase from rat adipose tissue. Biochim. Biophys. Acta. 218: 333.

21. Heller, R. A., and D. Steinberg. 1972. Partial glyceridase activity of a protein-kinase activatable triglyceride lipase from rat adipose tissue. Biochim. Biophys. Acta. $270: 65$.

22. Wieland, O. 1963. Glycerol. In Method of Enzymatic Analysis. H. U. Bergmeyer, editor. Academic Press, Inc., New York. 2nd edition. 211.

23. Lowry, O. H., N. J. Rosebrough, A. L. Farr, and R. J. Randall. 1951. Protein measurement with the folin phenol reagent. J. Biol. Chem. 193: 265.

24. Walsh, D. A., J. P. Perkins, and E. G. Krebs. 1968. An adenosine $3^{\prime}, 5^{\prime}$-monophosphate-dependent protein kinase from rabbit skeletal muscle. J. Biol. Chem. 243: 3763.

25. Walsh, D. A., C. D. Ashby, C. Gonzales, D. Calkins, E. H. Fischer, and E. G. Krebs. 1971. Purification and characterization of a protein inhibitor of adenosine $3^{\prime}, 5^{\prime}$-monophosphate-dependent protein kinase. J. Biol. Chem. 246: 1977.

26. Brown, W. V., and M. L. Baginsky. 1972. Inhibition of lipoprotein lipase by an apoprotein of human very low density lipoprotein. Biochem. Biophys. Res. Commun. $46: 375$.

27. Robinson, D. S., and D. R. Wing. 1970. Regulation of adipose tissue clearing factor lipase activity. In Adipose Tissue. B. Jeanrenaud and D. Hepp, editors. Academic Press, Inc., New York. 41.

28. Sutherland, E. W., and T. W. Rall. 1960. The relation of adenosine- $3^{\prime}, 5^{\prime}$-phosphate and phosphorylase to the actions of catecholamines and other hormones. Pharmacol. Rev. 12 : 265.

29. Larner, J., and C. Villar-Palasi. 1971. Glycogen synthase and its control. Curr. Top. Cell. Regul. 3: 195.

30. Krebs, E. G. 1972. Protein kinases. Curr. Top. Cell. Regul. 5 : 99.

31. Corbin, J. D., C. O. Brostrom, R. L. Alexander, and E. G. Krebs. 1972. Adenosine 3',5'-monophosphate-dependent protein kinase from adipose tissue. J. Biol. Chem. 247: 3736.

32. Patten, R. L. 1970. The reciprocal regulation of lipoprotein lipase activity and hormone-sensitive lipase activity in rat adipocytes. J. Biol. Chem. 245: 5577.

33. Nikkilä, E. A., and O. Pykälisto. 1968. Regulation of adipose tissue lipoprotein lipase synthesis by intracellular free fatty acid. Life Sci. 7: 1303.

34. Sidhu, K. S., and R. S. Emery. 1972. Regulation of blood fatty acids and glycerol in lactating cows. $J$. Dairy Sci. 55 : 926. 